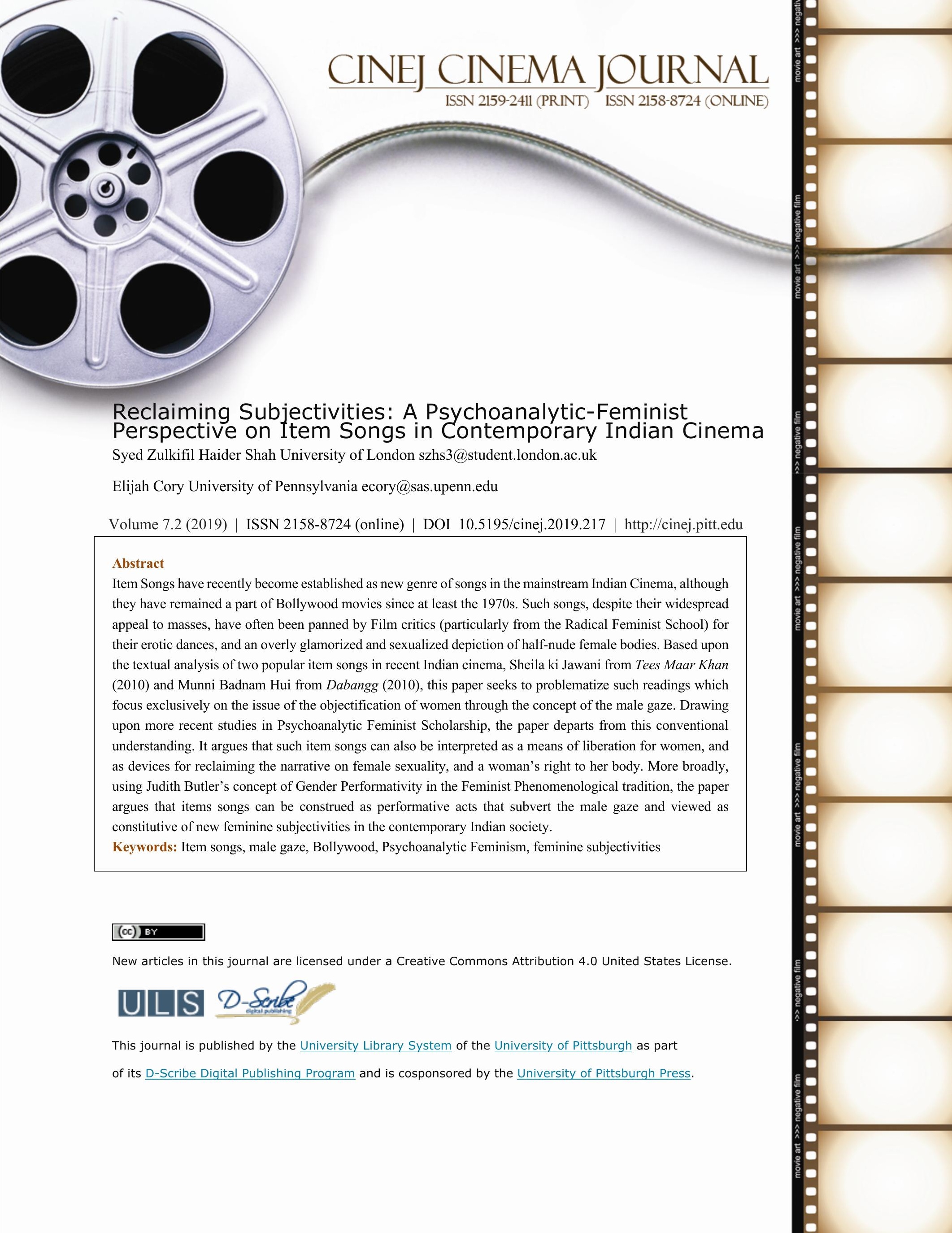




\section{Reclaiming Subjectivities: A Psychoanalytic-Feminist Perspective on Item Songs in Contemporary Indian Cinema}

\section{Syed Zulkifil Haider Shah and Elijah Cory}

This paper aims to examine the concept of the vamp and female item song performers in contemporary Indian cinema. Item songs, in Bollywood movies, refer to songs that 'are almost exclusively non-situational songs... with lavish and large-scale picturizations that often play an extra rather than pivotal role in the narrative'1. These item songs allow for a 'more seductive display of female flesh than has been traditionally allowed for the Bollywood heroine'2.

The item songs are often noted for their objectifying features in general have always attracted the public censure of feminists for the most part. For instance, notable feminist scholars such as Andrea Dworkin (1989), Laura Mulvey $(1988)^{3}$ and more recently Cynthia Carter (2000) ${ }^{4}$, have argued how images of female bodies in media represent women as passive objects of male sexual desires and have condemned erotic depictions of women for their misogyny and as a form of sexual violence. However, the paper sets out that despite their overtly sexual portrayal of women, such item songs are not objectifying women. Rather, the paper argues that such item songs performances, while bordering on a soft version of eroticized depictions of female bodies- are serving as an important means to empower women, and are ways of reclaiming the narrative on female sexuality, gender roles and a woman's right to her body and more generally her life. The 
paper argues that such songs can be seen as performative acts in Judith Butler's terms ${ }^{5}$, that are constitutive of feminine subjectivities in contemporary Indian society.

We argue in this paper that item numbers intentionally subvert the (heterosexual) male gaze, and they do so through creating a spectacle of female sexuality. To support/demonstrate our argument, we will present a textual analysis of the famous item songs 'Munni Badnaam' from Abhinav Kayshap's Dabang ${ }^{6}$ (2010) and 'Sheila Ki Jawani'7 from Farah Khan's Tees Maar Khan $(2010)^{8}$.

In order to understand the reception of Item songs, it is pertinent to understand the gender roles in Indian culture. In India, there has always been shame around sex and women. Prostitution, open liberal social contact with women and access to pornography are all restricted. In modern India, the sexualized and "dirty" nature of "notorious" women are stereotyped by stories of courtesans, prostitutes and vamps ${ }^{9}$. Visiting prostitutes is restricted or brings shame and hence the public male encounter with or the imagination of female sexuality has always been a secretive, taboo or closed and repressed one.

Hence, given this secrecy, restriction, mystery and charm around them, the item songs become a somewhat acceptable way to come to terms with and engage with women and sexuality on a public/ open level. Although, as Ganti argues, 'the film industry is perceived as a morally 
hazardous space for women... the very fact of being an actress brings a woman's sexuality into the foreground, marking her as an openly sexual being, in a manner not experienced by a male actor" ${ }^{\prime 10}$. However, the item song pushes this sexualization to a whole new level. As Kumar argues the item songs become 'an avenue to repackage one's personae in a seductive module'11. It is due to this sexualization that vamps can be seen as constituting danger (impurity, cunningness, or ideas that vamps and courtesans cannot be trusted).

\section{SHEILA:}

money, car, a luxurious house $e^{12}$

I need a man who can give me all that

broke?!

No, no, I don't like it like that

Here, the performer is invoking the common misconception and stereotype that a sexual woman is dangerous and evil (for instance, she only wants a man for his wealth). But the clever thing is that by expressing this, the woman is not objectifying herself as a greedy "slut". Rather, she's ridiculing men that she doesn't need them, but only their wealth. She hints that the men do not exist for her except for their wealth. On the performer's part, this can be seen as subversive of the male gaze as women objectify men and hence respond to men in their (allegedly) unique ways.

For instance, just as some men want woman for sex and deny their status as equal humans, the 
performer conforms to this cliché and says yes, I want only your wealth and you (man) don't even exist for $\mathrm{me}^{13}$.

Despite such open ridicules aimed at men, the item song appeals to men because it allows them to bring to forth their precisely repressed sexual emotions ${ }^{14}$. It allows them to project women in their stereotypical image and as cunning, opportunistic and greedy. The item numbers gain popularity because they make a woman appear to man in a way he's been trained to think of her, [ vulnerable and drenched, revealing her seductive body) $]^{15}$ and in a way which is familiar and unintimidating, and this familiar and unintimidating context is one of a sexual person, a marginal existence in and of herself.

\section{The MALE (from Munni):}

There is intoxication of a whole Bottle in you, You make even old-age young, you make it young,

There's a swear word on your tongue and your eyes are (red) like gulaal You became smoking hot, for me darling

Munni got infamous, darling, for me

Since the everyday encounter with females in India is always socially guarded, it is this restricted encounter which gives the item song an element of grandiose exaggeration: play, fantasy and symbolic fulfillment of sexual desire. This fantasy and play in the item song is maintained through carefully controlled attributes such as clothing, direction, lyrics and narrative. For 
instance, regarding the half-clothed yet provocative bodies of performers in item songs, Stella Bruzzi argues that "superficially restrictive clothes function as equivocal signifiers, acting both as barriers to sexual expression and as the very means of reaching sexual fulfilment" ${ }^{16}$. For instance, the carefully worded lyrics and dance sequences of the item songs "Sheila" and "Munni" elucidate how and why the male viewers derive pleasure as this play of fantasy is maintained by a game of absence and presence: the performer is both nude and clothed, and the dancer moves very close to the audience and then goes back again in a teasing way.

Before moving further, it would be helpful to visualize the picturization of the Sheila Song. In the Sheila song, "the video starts with a shot of a film studio that advertises the sign 'Blue Film Presents Sheila Ki Jawani'. There is a lecherous-looking film crew and the director watching, as Anya (Kaif) starts the song draped in a pink bedsheet, sitting on a bed, beating her chest wildly, as the black-clad men that surround her- also on the bed - rock their pelvis'. Anya, contrary to the appearances, sings the lyrics, 'I know you want it, but you're never gonna get it, in both Hindi and English"17. Correspondingly, Pugsley notes that "the focus on Sheila reiterates the way that items act as a crucial part of Indian films where the audience gaze is invited to certain parts of the body selectively considered sexual"18.

SHEILA:

I know you want it,

But you never gonna get it

you're never gonna get your hands on me 
whether the world acknowledges it or not

it's crazy for my attention

However, here, we see again that the performer has the upper hand on her sexuality. Her tone is authoritative, teasing and playful. She is exercising her control over the men by saying, "I know you want it," which puts men into a position of dependency. Similarly, she teases them with the line, "But you never gonna get it." This can be likened to what Mary Ann Doane refers to as the adult version of the Fort-Da Game. The Fort-Da Game refers to Freud's account of how his grandchild, an infant, was able to derive pleasure from throwing a cotton-reel string away from himself and then pulling it back. This game, Freud argued, allowed him (the infant) to the come to terms with the disappearance and reappearance of his mother ${ }^{19}$. This game signifies how the child comes to attain a sense of mastery through the symbolization of the loss of the object of desire (his mother).

In this case, the Fort-Da ("here it is"- "it goes") allows male viewers to attain mastery over their erotic desire and to mediate the lack of the object of desire (the woman's body). By allowing themselves to be teased repeatedly, they symbolically replace what they want (a real woman's body) and derive pleasure from it. They watch on the screen how the performer woos them and then teases them and goes away - and this continues for the duration of the song as the lyrics and 
dances repeat. This game of fantasy is so pleasurable that it fixates male viewers, drawing them back to the cinemas to watch the film again and again ${ }^{20}$.

The reason why item songs are enduringly popular can be explained through the psychoanalytic concept of the male gaze. Psychoanalysis is pertinent here because of its success in explaining the complexity of human subjectivity and how the male viewers' deepest erotic desires are mediated through the language of symbols such as dance moves and lyrics. Here, the performer and her body become symbols--screens on which the male viewer projects his inner desires.

\author{
MALE from Sheila: \\ Alas! I've been thirsty for your body as if for a hundred years now \\ Your glance falls upon me as if a rain cloud on my dry body
}

In that moment, one may argue that the woman's body becomes empty of her individuality and becomes a symbol or object of lust. However, we argue that it is not so because the female body is not a passive object for the male audience's gaze. Rather, the female performer retains full control of the situation. She cashes upon her sexuality and voluptuousness to trap males in their own gaze in a gesture of submissive role-reversal.

MALE from Sheila:

Let's get out of here (in private), I'll bring you everything

I'll place all the pleasures of the world at your feet

I'll fulfill all your dreams

You know I am gonna love you like that 


\section{SHEILA:}

Whatever

Here, the man submits to and falls prey to her charms, accepts her lead and shows his dependency. Thus, as Gehlawat (2015) argues the male gaze is subverted here by referring to the men's desperate desire for the woman's body: the man is imploring and the woman is inacquiescent, and in the end, she shows her extreme indifference and rejection of him by saying, "whatever."

It is interesting to note here that the performer consciously presents her body as an object of display. However, the control here ultimately lies with the female performer, who is a master of the illusion - the simulacra. The male viewers are successful in objectifying the woman but it is the woman who enjoys making a fool out of the men, and taking delight in controlling them and wooing them.

\section{SHEILA:}

Silly silly silly boys

Those who follow me everywhere

When you look at them

They whisper to themselves timidly

Their schemes can't woo me 
Here, she's mocking masculinity by calling men silly and ridiculing their attempts to seduce

her. She is a dominating personality, one which the boys cannot dare to look at or talk to, and instead they talk to each other in whispers. Thus, we see a role reversal: the woman here takes charge and the men become passive, slow, whisperers, incapable of controlling her.

\author{
SHEILA: \\ What's my name? \\ what's my name? \\ what's my name? \\ My name is Sheila, Sheila ki Jawani \\ I am too sexy for you \\ You're never gonna get your hands on me!
}

Again, the performer is teasing the men and referring to her youthful body and beauty. We see how she appeals to men's fantasy and erotic desire by invoking her youth, and beauty. She is also appealing to the traditional image of woman by embodying it: she's mysterious, elusive, seductive, and voluptuous. The performer here is masterfully trapping the male gaze into perceiving exactly that which the male wants to perceive, and in doing so becomes empowered through this subversion of the male gaze. Thus, with a clever twist, the woman reclaims her sexuality and her womanhood as she says, "You're never gonna get your hands on me!".

Here, the success of the female performer is in undoing the male gaze by way of overdoing it; the performer does what the male viewer wants her to do, and to be what they think of her. Thus, the male viewer is led to see a particular type of woman with whom he has a certain, previous 
cultural familiarity (for instance, as mentioned before, the woman depicted by adjective such as:

seductive, vamps, femme fatales, courtesans, prostitutes, etc.). These perceptions of women are always exotic and mysterious and invoke a sense of women as objects of male sexual desires. In Williamson's (1998) words women appear as "passive repositories of (males') desires", and as entities whose identity is governed by a patriarchal narrative ${ }^{21}$. Thus, the women perceived by the male gaze are intriguing characters: seductive, appealing and fascinating 22.

Thus, the performer lets the viewer construct an artificial stereotyped femininity-a simulacrum $^{23}$, through stylistic and cultural cues. We call them artificial because the stereotype offers a limited view of the complex feminine subjectivities, and they are artificial because they are mere projections of the male gaze rather than representative of women in their complex actuality. Such views of female figures and dancers are informed by the cultural images of courtesans and dancing notch girls ${ }^{24}$. However, the male gaze is undone because the very idea of a woman controlling access to her body and the narrative about it. This reclaiming of control is evidenced by the fact that the performer is shown to be singing the song herself [despite its being lip synced] and the song is in about her. This goes on to show that she is a not a passive object of male desire. Rather, she, in her manipulative way, appears as a being with her own agency and complex psychology. 
Since, arguably, in Indian society and cinema, women are primarily seen as sexual beings, the item songs are successful with male viewers because they place undue emphasis on women's sexuality as a marker of their identities. However, in a clever subtle twist, the item song tries to overdo the connection of sexuality with women so much that it no longer retains its patriarchalideological meanings. In other words, the item songs are an ironic way of mocking the patriarchy by repeating it.

\section{MUNNI:}

What a naïve amateur have I come across

He's broke and has nothing to offer me

This idiot doesn't know that even Saifu ${ }^{25}$ is all crazy for me...

This 'item 'makes herself available, darling, only for you

This 'item 'makes herself available, darling, only for you

Munni became disgraced, darling, only for you

Here in this excerpt, the performer is referring to the popular perceptions associated with a promiscuous woman in a patriarchal society that wishes to moralize and control her sexuality ${ }^{26}$. Here the performer lets the men see her through a patriarchal lens: she has as expected, a team of jealous lovers whom she sleeps with for money. Here, by talking about being common, she's voicing the men's fantasy of having sex with her. In other words, by making her common, she's devaluing herself and making herself available for men's erotic pleasure. The song constantly refers to how Munni's become disgraced for her lover (perhaps by having sex with him). It's a 
subtle and clever jab at patriarchy. The lyrics connote that Munni did all this for her lover, and yet it's Munni who's blamed and disgraced for her "promiscuity" and not the male lover who remains morally unblemished! Here, the item song is addressing this gender discrimination and the attitude of slut-shaming in the Indian society. Thus, it can be argued that the item songs are indirectly trying to expose gender discrimination and attempting to shame patriarchal assumptions of gendered morality.

Munni's disgrace, the title of the song as well as the refrain, also refers to a female performer's ease with her sexuality. Munni literally means a (feminine) small or young one, and is often used to refer to a young, naive, pre-adolescent girl. Hence in this song, the badnami refers to loss of Munni's sexual innocence and suggests her sexual coming of age (albeit in a manner of what is termed as socially constructed "disgrace").

Although the Munni is addressing to a lover, she's in full control of her sexuality and her identity and she seems to be enjoying her notoriety. Conventionally, this sort of notoriety leads to women's persecution and exclusion from Indian society. The performer, through this item song comes across as a badass! She's enjoying it, and her attitude is patronizing towards her male love as she's constantly saying, I became this and that, Darling, for you only! Here, darling is used in a sarcastic tone, and not with a soft touch of love. Her attitude is that of an indifferent person who 
mocks at society and at her lover while she enjoys her ill-repute. Thus, we see how item songs become a way to claim independence from narratives on women which identify women by their sexual nature, and by such identification shame and trap them morally.

Thus, the way to deconstruct this stereotype and to liberate women's identity from oppressive sexual morality is only possible through laying open the myth about women's sexuality ${ }^{27}$, by accepting the claim initially, and then over -engaging with it in public until the taboo, shame and myth about sexuality is desensitized, challenged, pushed back or disappeared. By showing women as masters of their bodies, item songs seek to desensitize the highly stringent moral codes pertaining to women's sexual identities. By vulgarizing sex, the moral codes can be subverted, and the control over female bodies be reclaimed by females through a symbolic play of dance and lyrics in the item song.

On a related note, the item song also sends a message that the women in the performance is ridiculing the male gaze while simultaneously enjoying being the center of attention. The male gaze is subverted here because the performers ridicule, mock and tease the male viewers as an indirect means to shame men for their gullibility in falling prey to the women's charms.

\section{MUNNI:}

I have Shilpa's figure and Bebo's style

In my jerk, there is pleasure of a movie,

You don't know my attitude,

Yeah, you don't know lacs of Rupees are spent on my attitude

That I became a mint (place where coins are made), for you darling 


\section{Became a Cinema hall, for you darling}

This excerpt refers to how an item song sells sheer fantasy. Bebo and Shilpa are considered to be sex symbols as they are considered among some of the most attractive female actors in India. So, by alluding to cinema and actresses, she's referring to the men's most erotic desires about female sexuality. She is wooing men in their fantasy and claiming to be an attractive girl of such seductive potential. By doing so, the woman becomes her own authentic voice on her sexuality and charm. Although it's a man's desire about sex which she is referring to but the voice is a female one shaming men and exposing them for their hidden fantasies.

The shame here is also to do with the depth of the performers' cunning and manipulative emotions and gestures through which she belittles the status of men. It reveals that women are not merely passive objects or repositories of desire. Rather the depicted women's complexity as thinking and feeling beings portray them as intellectually and emotionally capable subjects. It is only through accepting them as equal subjects, independent of men, that the women will be empowered.

\section{SHEILA:}

Now I feel like, slowly

Embracing myself

What need I have of anyone else?

why shall I not pamper myself 
This excerpt can be interpreted as a clear attempt to establish feminine subjectivity as independent of males and to break away from the idea that women are passive objects of desire existing merely to satisfy the sexual needs of men. Lastly, we can argue that the item numbers empower women because they allow a creation of a mass-subjectivity of women through mass media. It's (the item songs') success lies in linking and channeling the male viewers' private fantasies and experiences with sex and women to the public perception of women. By putting women out there performing and singing, it allows viewers to express their private experiences and to give voice to their imaginations of sexuality in a pleasure-inducing way. It is through controlling and channeling this element of pleasure that item songs have the potency to sway the public perception of women in a way they may wish to.

Thus, using Straussian analogy, item songs can be likened to myths in a culture. Like myths, item songs arise out of and as an expression of our collective unconscious and its deep desires, motivations, emotions and thoughts ${ }^{28}$. Like mythical tales, the item songs contain elements of fantasy woven in a narrative which contradicts our commonsensical, everyday logic of things ${ }^{29}$. For instance, it is alright for a woman to remain half-nude and mock men, which she can't do outside this narrative, in a normal social setting. However, despite the para-logical suspension of common sense and our deeply held beliefs, myths retain an important place in our worldview because the idea and desires they express are primal and cannot be discarded. Hence, 
they remain there, posing an open contradiction within our beliefs and yet appeal to us because of

our fantasies. Similarly, one may argue that item songs are bound to remain popular in the patriarchal Indian society despite their contestation of gender norms.

\section{REFERENCES}

${ }^{1}$ Morcom, Anna. "The Audience Reception of Hindi Film Songs in and beyond the Parent Film."

Hindi Film Songs and the Cinema. Hampshire: Ashgate, 2007. 212. Print.

2 Nijhawan, Amita. "Of Snake Dances, Overseas Brides, and Miss World Peagants." The Oxford

Handbook of Dance and the Popular Screen. Ed. Melissa Blanco Borelli. Oxford : Oxford

University Press, 2014. 385.

3 Mulvey, Laura. "Visual Pleasure and Narrative Cinema." Feminism and Film Theory. Ed.

Constance Penley. New York: Routledge, 1988. 57-68. Print.

${ }^{4}$ Carter, Cynthia. "Mass Media." Encyclpedia of Feminist Theories. Ed. Lorrain Code. London:

Routledge, 2000. Print.

${ }^{5}$ Butler, Judith. "Performative Acts and Gender Constitution: An Essay in Phenomenology and Feminist Theory." Theatre Journal (1988): 519-531. Print.

${ }^{6}$ Dabangg. Dir. Abhinav Kayshap. Perf. Malaika Arora. Arbaaz Khan Productions, 2010. Transcript.

7 Tees Maar Khan. Dir. Farah Khan. Perf. Katrina Kaif. UTV Motion Pictures, 2010. Transcript.

${ }^{8}$ The credits for the songs are reproduced from Mazumder's chapter in the Routledge Handbook of Indian Cinemas: "Munni Badnam hui (Munni has been scandalized) in Dabangg (Fearless, 2010) composed and written by Lalit Pandit, sung by Mamta Sharma and Aishwariya; and 'My Name is Sheila' in Tees Maar Khan (2010), composed by Vishal-Shekhar, written by another famous lyricist Javed Akhtar and sung by Sunidhi Chohan" (Mazumder, 2013: 266). The full bibliographic citations for these works are as follows: Mazumder, Premendra. "Music in Mainstream Indian Cinema." Routledge Handbook of Indian Cinemas. Ed. Moti Gokulsing and Wimal Dissanayake. New York, 2013. 257-268.

${ }^{9}$ Gehlawat, Ajay. "Reconstructing Femininity: From the Vamp to Bollywood's New Woman." Twenty-First Century Bollywood. New York: Routledge, 2015. 40-65. Print.

10 Ganti, Tejaswani. "Casting Respectability." Producing Bollywood: Inside the Contemporary 
Hindi Film Industry. Durhan: Duke University Press, 2012. 135. Print.

${ }^{11}$ Kumar, Akshaya. "Item Number/Item Girl." South Asia: Journal of South Asian Studies 40.2 (2017): 338. Online.

${ }^{12}$ All translations from original Hindi lyrics are our own unless otherwise stated.

${ }^{13}$ This notion of subverting the male gaze by its very own apparatus has received renewed interest in recent debates among Radical feminists. See for instance, Dolan (2012) [Dolan, Jill. The Feminist Spectator as Critic. Ann Arbor: University of Michigan Press, 2012. Print.]; and Hollows (2000) [Hollows, Joanne. "Film Studies and the woman's film." Feminism, Femininity and Popular Culture. Machester: Manchester University Press, 2000. Print.]

${ }^{14}$ Shresthova, Sangita. Between Cinema and Performance: Globalizing Bollywood Dance.

Thesis. University of California, 2008. Ann Arbor: ProQuest LLC, 2008. Print. 50.

${ }^{15}$ Mishra, Smeeta. "Negotiating Female Sexuality: Bollywood Belly Dance, "Item Girls" and

Dance Classes." Belly Dance Around the World: New Communities, Performance and Identity. Ed. Caitlin McDonald and Barbara Sellers-Young. North Carolina: McFarland \& Company , 2013. 181-196.

${ }^{16}$ Banaji, Shakuntala. "Loving with Irony: Young Bombay Viewers Discuss Clothing, Sex and

Their Encounters with Media." Sex Education 6.4 (2006): 384. Web. 1 Dec. 2015.

${ }^{17}$ Nijhawan, Amita. "The Item Girl: tradition and transgression in Bollywood Dancing." Salaam

Bollywood: Representations and Interpretations. Ed. Vikrant Kishore, Amit Sarwal and Parichay

Patra. New York, 2016. 150.

18 Pugsley, Peter. "Indian Cinema's New Aesthetic." Exploring Morality and Sexuality in Asian

Cinema: Cinematic Boundaries. New York: Routledge, 2016. 29. Print.

${ }^{19}$ Doane, Mary Ann. "Epistemology as Strip Tease." Femmes Fatales: Feminism, Film Theory, Psychoanalysis. New York: Routledge, 1991.102. Print.

${ }^{20}$ Ganti, Tejaswani. "Production and Distribution." Bollywood: A Guide to Popular Hindi

Cinema. New York: Routledge., 2004. 98. Print.

${ }^{21}$ Williamson, Judith. "A Piece of the Action: Images of "Woman" in the Photography of Cindy

Sherman." Consuming Passions: The Dynamics of Popular Culture. London: Marion Boyars, 1988. 91-112. Print.

22 These features of the Male gaze remain some widely-established points of departure for Feminist interventions in Film Criticism particularly in Hollywood and French Cinema. See for instance, [Fol, Isabelle. The dominance of the male gaze in Hollywood Films: Patriarchal Hollywood Images of Women at the Turn of the 
Millenium. Hamburg: Diplom, 2006. Print.]; [Johnson, Merri Lisa. "Boy Spectators and Boy Culture." Third Wave Feminism and Television:

Jane Puts It in a Box. Reading Contemporary Television. New York: I.B. Tauris, 2007. 147-192. Print] and more recently, Bloom, James D. Reading the Male Gaze in Literature and Culture: Studies in Erotic Epistemology. Allentown: Palgrave McMillon, 2017. Print.

${ }^{23}$ The term is used here in the sense of Jean Baudrillard (1994) in his classical work, Simulacra and Simulation. Trans. Sheila Faria Glaser. Ann Arbor: University of Michigan Press, 1994.

Print.

${ }^{24}$ Ganti, Tejaswani. "Introduction." Bollywood: A Guide to Popular Hindi Cinema. New York:

Routledge., 2004. 1-22. Print.

${ }^{25}$ Allusion to Saif Ali Khan, a popular contemporary Bollywood film actor.

${ }^{26}$ Pillai, Meena. "Matriliny to Masculinity: Performing Modernity and Gender in Cinema." Ed. Wimmal Dissanayake. Handbook of Indian Cinemas. Ed. K. Moti Golkulsing. Oxon: Routledge, 2013. 102-14. Print.

${ }^{27}$ Pollock, Griselda. "Screening the seventies: sexuality and representation in feminist practice- a Brechtian Perspective." Vision and Difference: Feminism, Femininity and Histories of Art. Routledge, 1988. 212-267. Print.

${ }^{28}$ Lévi-Strauss, Claude. Myth and Meaning. Toronto: University of Toronto Press, 1978. Print.

${ }^{29}$ See for instance, Fallaize, Elizabeth. "Simone de Beauvoir and the demystification of woman." A History of Feminist Literary Criticism. Ed. Gill Plain and Susan Sellers. Cambridge: Cambridge University Press, 2007. 85100. Print. 